\title{
Twin Vortex and Kármán Vortex visualized by Jyoumon-jin
}

\author{
Yasuki Nakayama, Katsumi Aoki and Makoto Oki
}

\begin{abstract}
It is said that the Jyoumon Age Culture continued from 16,000 years ago to 2,500 years ago and the people who bore the culture is called Joumon-jin. Earthen ware that were produced by Jyoumon-jin are called Joumon-doki. Jyoumon-doki have been discovered in various parts of Japan and there are many kinds of them. Among them, one discovered at Umataka-ruins in Niigata Prefecture at the end of 1931 is very famous for its nice patterns and it was named Kaen -doki.

The patterns on its lip and side wall are related to the water flow, the authors believe. The nice vortex patters of Kaen-doki put on their side wall are two kinds of vortex observed down stream of piles and rocks in the river acting the pollen and fallen leaves, etc. as tracers.
\end{abstract}

This fact was appeared again using Floating Tracer Method, one of the visualization methods of modern age, and the computer simulation.

Keywords: Joumon-doki, Visualization, Twin vortex, Kármán vortex, Computer simulation

\section{1. 緒 論}

縄文時代は今から 1 万 6 千年前に始まり，2千 5 百年 前に至ると言われている，その文化をになった人々が縄 文人である．この縄文人の作成した土器を縄文土器とい っている. 縄文土器は日本各地で発見され, 沢山の種類 があるが，1931 年 12 月 31 日新潟県長岡市郊外の馬高 遺跡の木立の中で発見された土器は Fig. 1 のような見事 な模様をもっている.この土器は 4,500 年も前のものと いわれている. その後, 日本各地で同じ様式の土器が次々 と発掘された。これらの土器はいずれもすばらしい形を しているが，馬高遺跡で発掘された土器のプロポーショ ンの良さは他を圧するものがある.

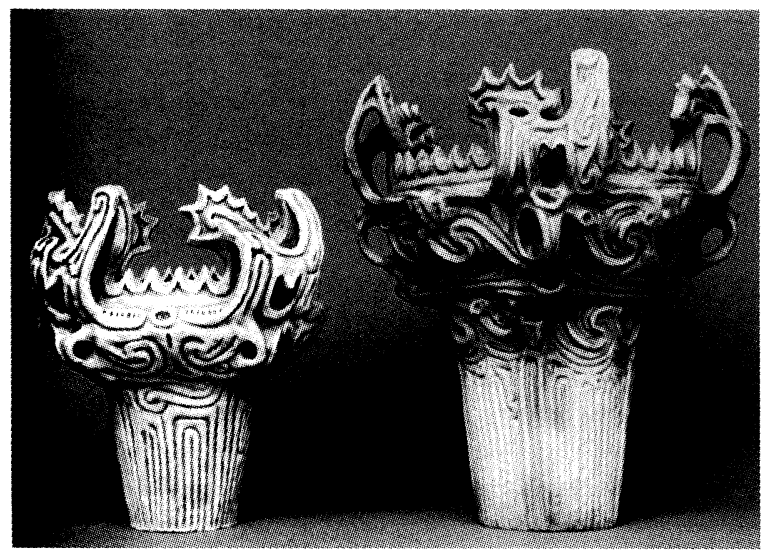

馬高遺跡(長岡市)

笹々山遺跡(十日町)

Fig. 1 Flame and water crest earthen vessel

(Kaen-suimon doki)
この土器は燃える火を連想して, 火焔土器と名付けら れているが，むしろ水との関連が深いように思う。すな わち, 開口部の模様は岩に砕ける大波に続くさざ波から も想像できるし，特に側面に刻まれた見事な模様は川の 岩や杭の後ろにできる渦からの造形である.

本報告は, 縄文人の眺めた自然の可視化の模様を推測し, この事実を現代の可視化技術を用いて再現し，コンピュ 一タ・シミュレーションによってその生成を明らかにし ようとするものである.

\section{2. 縄文人の可視化}

縄文土器の火焔土器の模様を展開してみると Fig. 2 の ようになる.この開口部の模様は火焔からの着想とも考 えられるかもしれないが，岩に砕ける大波に続くさざ波 からの着想とも考えられる，その下にある，側面に刻ま れた見事な渦模様は，明らかに二種類の渦から成り立っ ている．一つは回転方向が互いに反対な対象渦の双子渦 (Twin vortex) と呼ばれるもので, その下の回転方向の同 じ渦の連なった渦はカルマン渦（Kármán vortex）から の造形である. カルマン渦はある時には $\mathrm{S}$ 字形に，ある 時は逆 $\mathrm{S}$ 字形に見える。火焔からはこのような渦は見ら れない。

縄文人はおそらく川の流れに浮かぶ杉や松の花粉や落 ち葉や花びらなどをトレーサとして，川の杭や岩の後ろ にできる双子渦やカルマン渦を眺め, 土器に模様として 移したに違いない. 


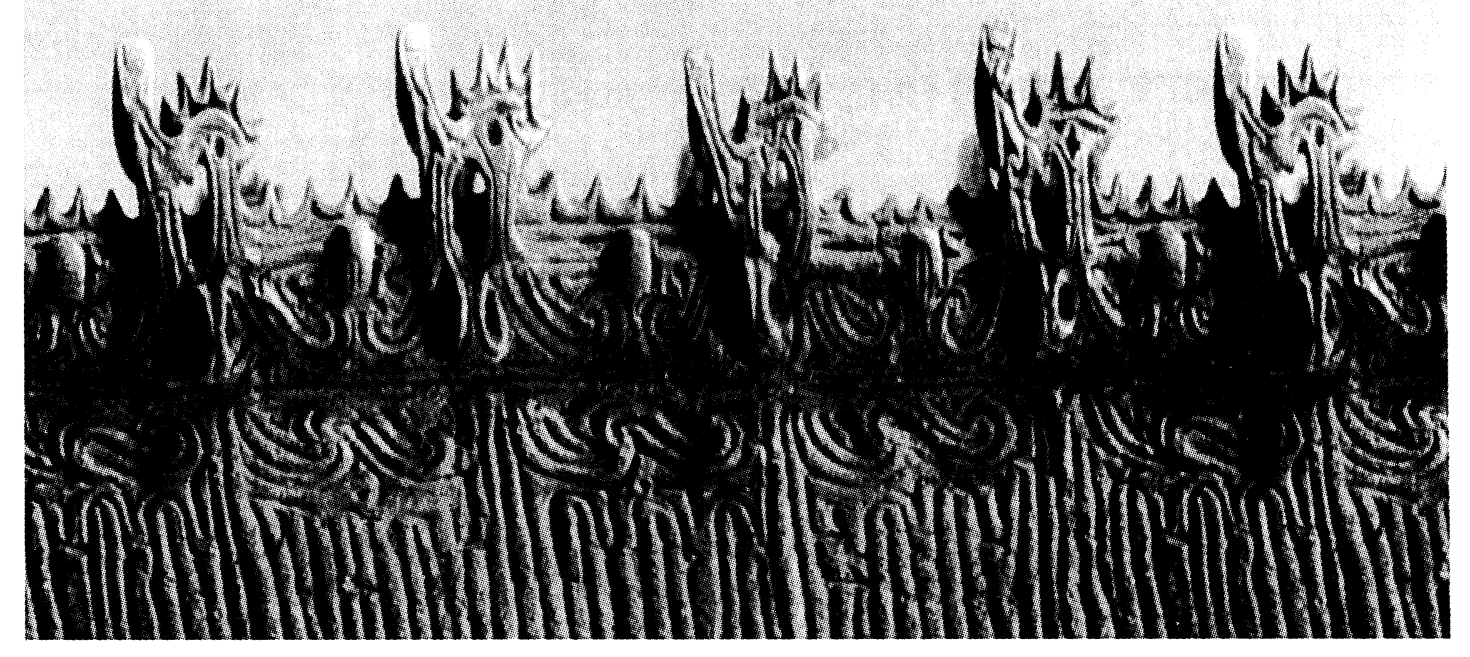

Fig. 2 Splendid pattern of Joumon-doki

\section{3. 縄文人の可視化の検証}

Fig. 3 は杉の林から出るおびただしい花粉の模様を写 した写真である.Fig.4に示す松からも同様におびただし い花粉が出る.

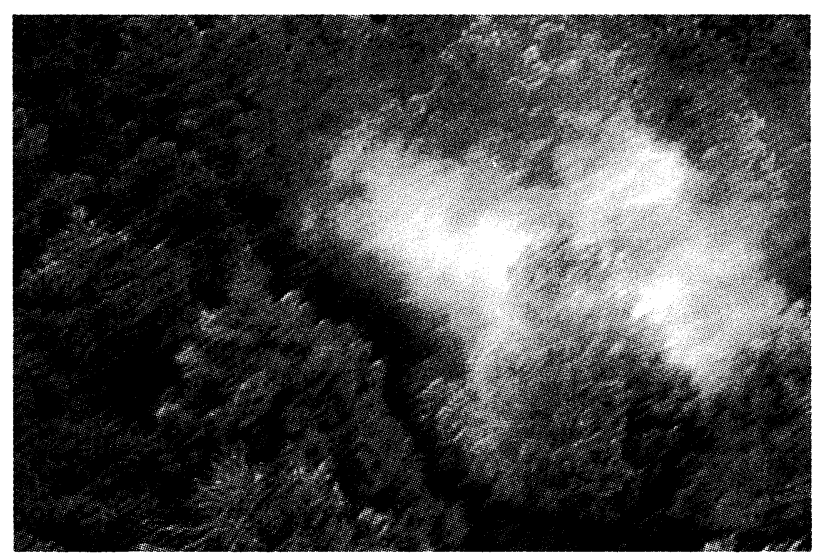

Fig. 3 Pollen of cedar comes from cedar forest

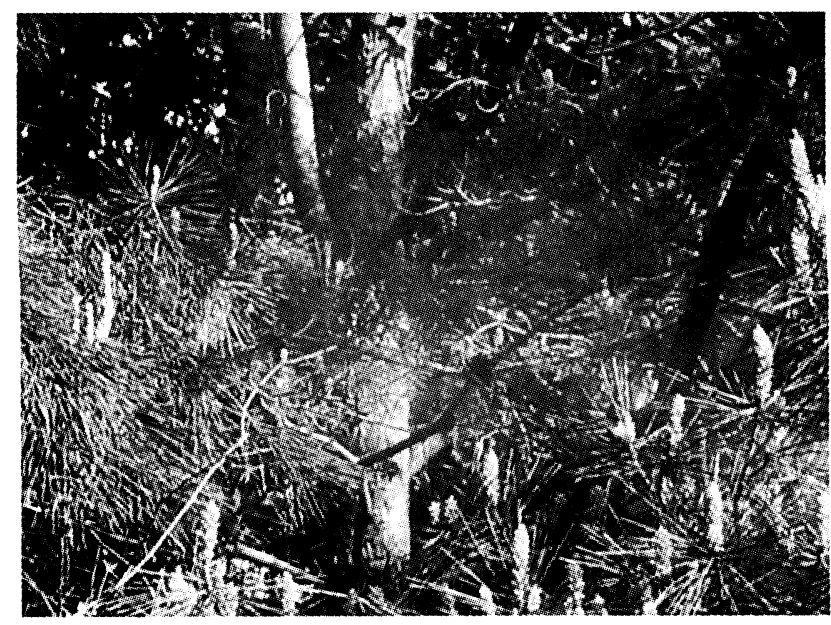

Fig.4 Pollen of pine tree comes from pine tree forest
これらが川面に落ちて格好なトレーサとなったこと は容易に想像できる.川面に浮かんだ落ち葉や花びらな ども優雅なトレーサとなったことと思う。

実際に川の岩の後ろに出来る渦をアルミ粉と杉の花粉 を使って可視化してみた. Fig. 5 が土器の上部に描かれ た方向反対な一対の渦模様で, Fig. 6 が下部に描かれ S 字型のカルマン渦模様である。このように, 側面の渦模

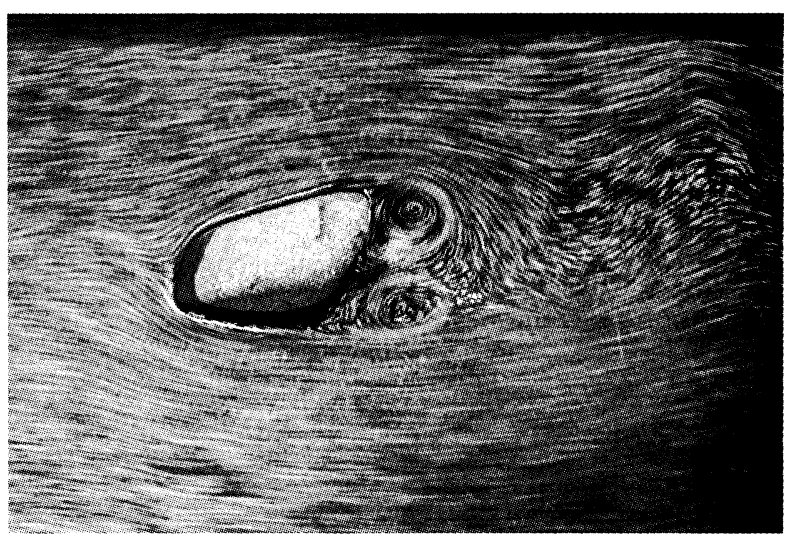

Fig. 5 Twin vortex behind a rock of river

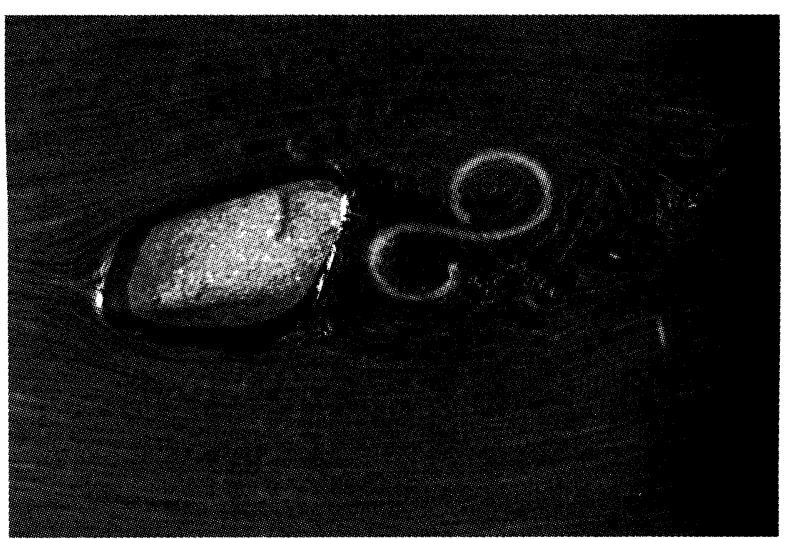

Fig: 6 Kármán vortex behind a rock of river 
様は水の流れから写したもので, 火からは着想できない. 従来の火焔という情熱的な発想も尊重し，本来の正しい 姿である水流の渦からの着想を取り入れ，この土器を火 焔水紋土器と呼ぶことを提案したい.

落ち葉や花粉の浮かぶ岩陰を流れる水の流れをじっと 見詰めているうちに，2 種類の渦を始めて観察して，土 器に移したのが縄文人だとなれば，そこに大きなロマン が生まれてくることになる.

自然に可視化が行われている例を Fig.7 に示す. カラ マツの葉がトレーサとなって, 小川の蛇行や渦を見事に とらえている.このような流れ模様を 17 世紀の画家尾 形光琳は有名な屏風絵 (Fig. 8)に残している.

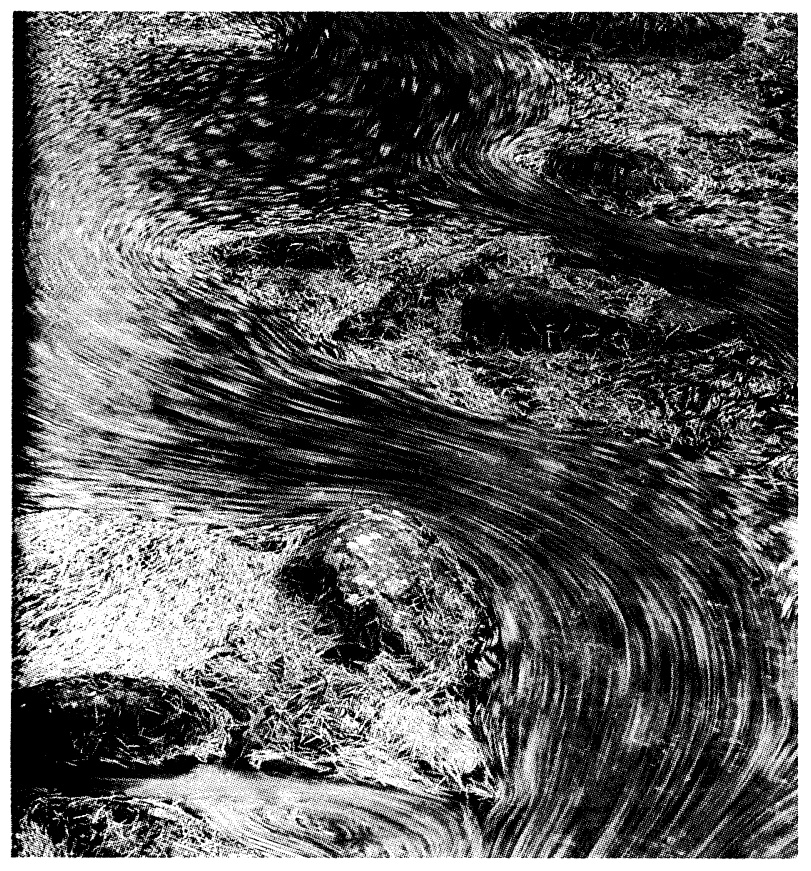

Fig. 7 Fallen leaves of larch tree floating on the surface of Azusa-river

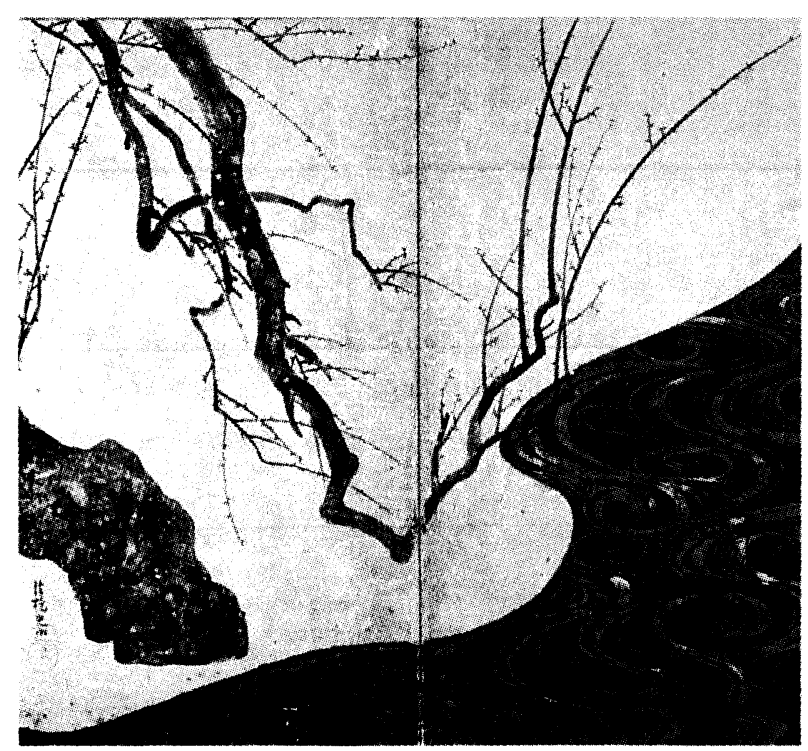

Fig.9 は三角柱後方のカルマン渦を水素気泡法で可視 化したものである. S 字形, 逆 S 字形の渦模様を明瞭に 表している.

Fig.10に四角柱背後の渦を二次元の平行流れとして差 分法により非定常のコンピュータ・シミュレーションを 行った結果を示す．この図を見ると双子渦からカルマン 渦へと成長してゆく過程がよくわかる。

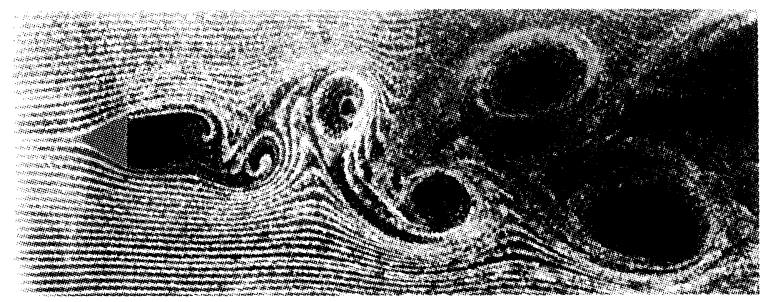

(a) Visualization by hydrogen bubble method

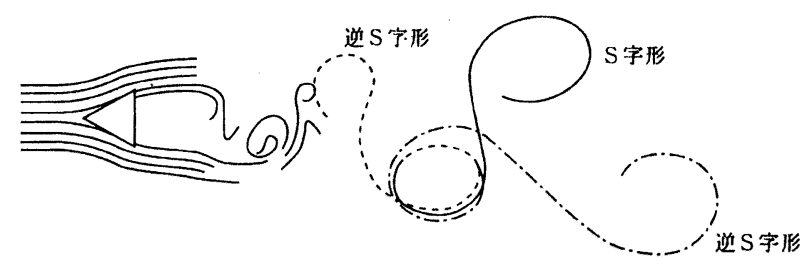

(b) Moment can be seen as S-shape or reverse S-shape

Fig. 9 Kármán vortex behind triangle column

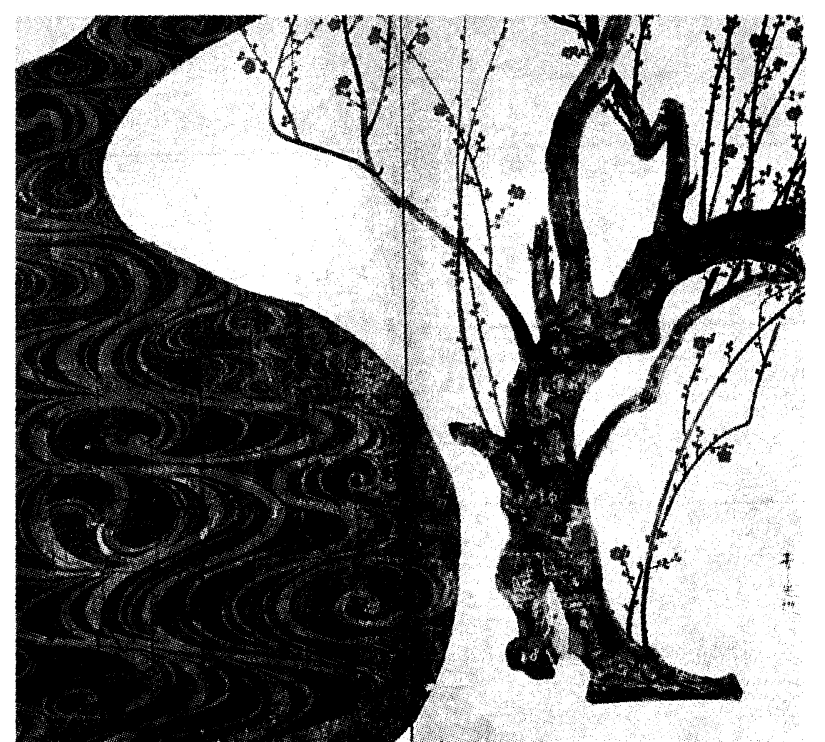

Fig. 8 Folding screen picture of Ogata Kourin 

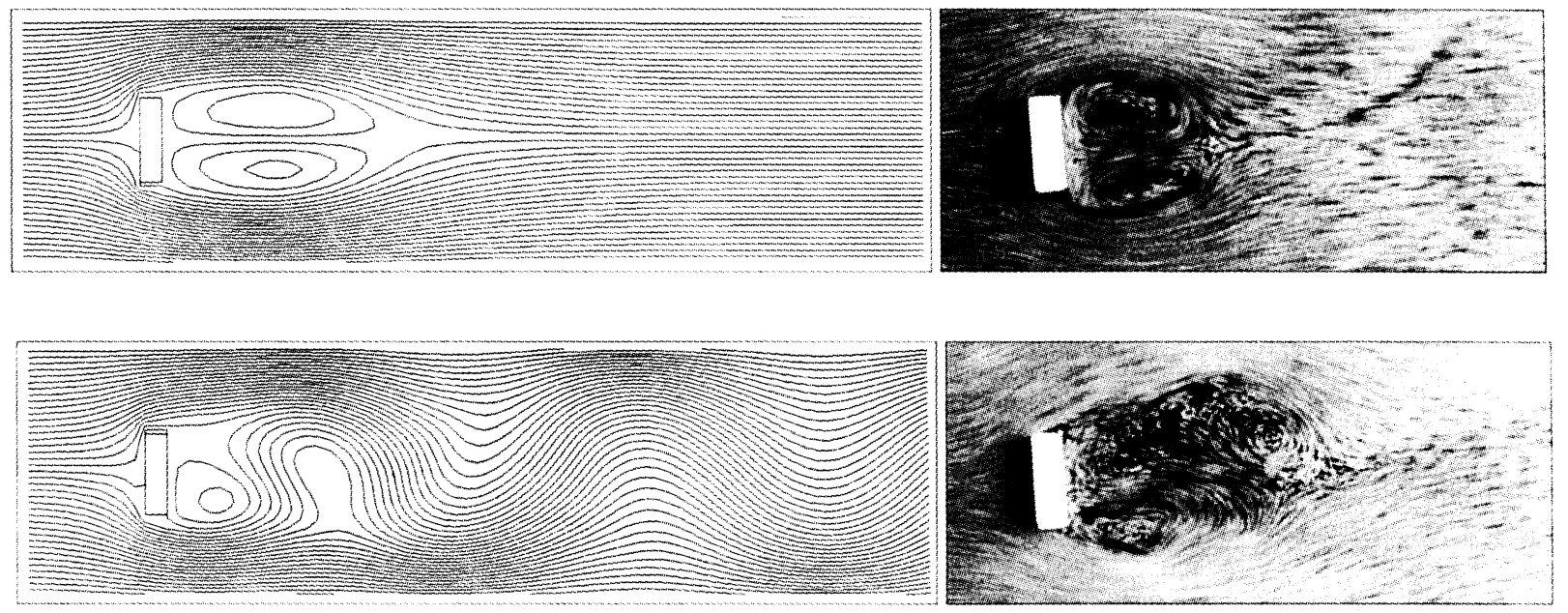

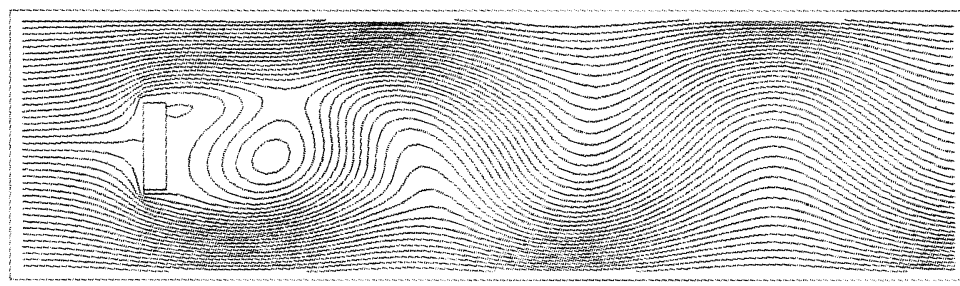

(a) Computer simulation

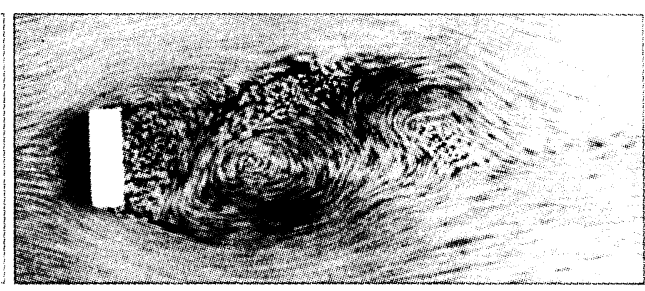

(b) Experiment

Fig.10 Vortex behind square column

\section{4. 結論}

1）縄文土器の開口部の模様は岩に砕ける大波に続くさ ざ波から思いついたものであると推定される。

2) 縄文土器の側面に刻まれた見事な渦模様は，川の岩 や杭の下流にできる双子渦とカルマン渦であることを 可視化実験とコンピュータ・シミュレーションにより 明らかにすることができた。

3）縄文土器の模様が水流に酔う渦からの着想であるこ とが明らかとなったので, 従来の火焔という発想も尊 重し, 本来の姿である水の渦からの着想を取り入れ, の同類の土器を火焔水紋土器と呼ぶようにすることを 提案する.

なお,花粉の採取にご協力頂いた東京電機大学亀岡利行 教授に厚く感謝の意を表します.

\section{参考文献}

1） NHK：日本その心と形 1. (1987) 70, 平凡社

2）可視化情報学会編, 可視化情報ライブラリー1, 流れの可視 化入門（1996），5，朝倉書店. 